\title{
Environmental Assessment of Bottom Ash from Canadian Coal-Fired Power Plants
}

\author{
Fariborz Goodarzi*
}

Geological Survey of Canada-Calgary Division, 3303-33rd Street N.W., Calgary, Alberta, Canada T2L 2A7

\begin{abstract}
Bottom ashes collected from ESP and baghouse of seven pulverized coal-fired power plants using subbituminous and bituminous coal and a fluidized bed combustor using crushed bituminous coal were examined for their mineralogy and elemental composition. The results presented in this paper are based on the average of three samples collected from each power plant. The mineralogy of each sample was determined using XRD and SEM/EDX; Elemental content was determined using INAA, ICPMS, and CVAAS; and the speciation of As, Cr, and Ni was determined by XANES. Bottom ash from the pulverized power plants consists of granular particles with a minor input of melted glassy fragments, while the bottom ash from the fluidized bed combustor consists entirely of granular particles. The sulphur and carbon contents of pulverized bottom ashes range from 0.03 to $2.32 \mathrm{wt} \%$ and 0.19 to $6.62 \mathrm{wt} \%$, respectively. For the fluidized bed combustor, the sulphur and carbon contents were $5.27 \mathrm{wt} \%$ and $10.72 \mathrm{wt} \%$. The concentrations of $\mathrm{As}, \mathrm{Cr}, \mathrm{Hg}, \mathrm{Ni}, \mathrm{and} \mathrm{Pb}$ in bottom ash are related to sulphur content of coal and are higher for bottom ashes from high sulphur feed coals. Most of the elements associated with $\mathrm{S}(\mathrm{As}, \mathrm{Hg}$, and $\mathrm{Pb}$ ) are captured from fluidized bottom ash, more so than by the corresponding ESP fly ash. Most of the elements in bottom ash have enrichment (RE) factors of less than 0.7 indicating that they are not enriched in the bottom ashes as compared to the feed coals. Arsenic, $\mathrm{Cd}, \mathrm{Cr}, \mathrm{Ni}$, and $\mathrm{Pb}$ have higher concentrations in granular bottom ash as compared to glassy bottom ash of the same power plant. The feldspars and quartz of feed coal are health hazards and are captured mostly by bottom ash and therefore prevent their emission from stack. The As, $\mathrm{Cr}$, and $\mathrm{Ni}$ in form of: non-toxic $\mathrm{As}^{+3}$, mostly beneficial $\mathrm{Cr}^{3+}$, and non-carcinogenic $\mathrm{Ni}^{2+}$ are in coordination predominantly with oxygen. Mercury and $\mathrm{Pb}$ are low and have very little environmental impact.The hazardous elements ( $\mathrm{As}, \mathrm{Cr}, \mathrm{Ni}, \mathrm{and} \mathrm{Pb}$ ) are only leached by $\mathrm{HCl}$, indicating that under normal condition they remain immobile and their impact on environment can be considered low.
\end{abstract}

Key Words: Bottom ash, coal fired power plants, elements, Canada

\section{INTRODUCTION}

Coal-fired power plant ash consists mostly of products from the decomposition and alteration of mineral matters in coal, a small amount of unburnt carbon (Clarke ICEA 1992[1], Cloke Fuel 1994 [2] Goodarzi GSC 2002 [3], Helle FPT 2003 [4]). Bottom ash forms up to $25 \%$ of the total ash while ESP fly ash forms the remaining 75\% (Stultz BWC 1992) [5].

In general, the bottom ash consists of two fractions: bulk, which is granular and porous particles; and minor (boiler slag), which consists of melted glassy fragments (Goodarzi GSC 2002) [3]. Bottom ash is used mostly for snow and ice control, as an aggregate in lightweight concrete masonry units, as raw feed material for production of Portland cements, for road base and sub base aggregate, as structural fill material, and as a fine aggregate in asphalt paving. Boiler slag is mainly used as blasting grit or roofing shingle granules (Hecht USEPA 1975 [6] Moulton USBM 1973 [7] ASTM 1997 [8] Lovell AMTRB 1991 [9] Moulton TRB 1973 [10]). Therefore, bottom ash has direct contact with our

*Address correspondence to this author at the Geological Survey of CanadaCalgary Division, 3303-33rd Street N.W., Calgary, Alberta, Canada T2L 2A7; E-mail: FGoodarz@NRCan.gc.ca living environment and its environmental impact is important. Bottom ash has low concentrations of volatile elements such as $\mathrm{Hg}$ and others, compared to ESP fly ash Sawine KAP 1995 [11]. It may also contain some unburnt coal and/or char fragments (Goodarzi GSC 2002) [3]. In general, for the pulverized coal-fired power plants the elemental concentrations in bottom ash are lower than that in ESP fly ash for most of elements (Goodarzi GSC 2002) [3]. Mineralogy of most bottom ash consists of silicates, with unburnt carbon/char contributing only a small fraction (Goodarzi GSC 2002) [3].

\section{ANALYTICAL METHODS}

Sampling: Bottom ash samples examined in this study were produced from seven pulverized coal power plants using low sulphur subbituminous feed coals (five samples) and one each from low sulphur bituminous feed coal, a high sulphur bituminous feed coal, and a fluidized bed combustor. Sampling was carried out according to the recommendations of the Electric Power Research Institute (EPRI 1994) [12]. Samples were collected over a period of three days at twohour intervals. These samples were then combined to produce a single sample for each day. Samples of bottom ash for each day were analyzed in duplicate, and then an average of 
analytical results was made of all three days to represent the bottom ash from each power plant.

Elemental Analyses: The carbon and sulphur analyses of ESP ESP fly ash were performed according to ASTM specifications (ASTM 1978) [13]. Elemental composition of samples was determined using some of the techniques recommended by (EPRI 1994) [12]; these included INAA, GFAA, CVAA, and ICPES. The ESP fly ash materials used for comparison were NIST1633b and SARM 19 and 20.

Relative Enrichment Index (RE): The power plant ashes can be classified into three classes based on their Relative Enrichment index (RE) and the degree of volatilization during combustion (Meij IT 2000) [14]. The RE is defined as:

$$
R E=\frac{E_{\text {ash }}}{E_{\text {coal }}} \times \frac{\% A s h_{\text {coal }}}{100}
$$

$\mathrm{E}_{\text {ash }}=$ Elemental concentration in ash

$\mathrm{E}_{\mathrm{coal}}=$ elemental concentration in coal

$\% \mathrm{Ash}_{\text {coal }}=$ percent of ash in coal

Class I. This includes the non-volatile elements and consists of major and rare earth elements, as well as Cs, Hf, and Sc. These elements have RE factors of $>1$ and are enriched in ash.

Class II. This includes elements that volatilize during combustion such as $\mathrm{As}, \mathrm{Ni}, \mathrm{Pb}$, and $\mathrm{S}$. These elements show RE factors of $<0.7$ and are redistributed into both the bottom and ESP fly ashes, and then they condense en-route to the stack (Goodarzi IJCJ 2006 [15] Meij 1995 KAP [16]).

Class III. These are highly volatile elements $(\mathrm{Cl}, \mathrm{Hg}$, and $\mathrm{Se}$ ), which almost entirely volatilized and emitted from the stack except for the portion that is captured by the carbon in the ESP fly ash (Hower IJCG 1993) [17] (EPRI 1994) [12]). These elements have very low RE factors.

Speciation of As, Cr, and Ni: X-ray Absorption Near Edge Structure (XANES) and X-ray Absorption Fine Structure (XAFS) spectroscopes were used to determine the oxidation states and modes of occurrence of arsenic, chromium, and nickel in bottom samples. For details of these procedures please see Goodarzi and Huggins (Goodarzi JEM 2004 [18] EF 2005ab [19, 20]).

Data Treatment: The data processing was same as described by (Goodarzi 2002 GSC) [3], which is consistent with the EPRI data collection procedures (EPRI 1994) [12]. Enrichment indices of the elements were determined according to Meij (KAP, 1995) [16].

Semi-quantitative Mineralogy: Semi-quantitative XRD analyses were carried out using corundum $\left(\mathrm{Al}_{2} \mathrm{O}_{3}\right)$ as an internal standard. This analytical technique is known as the reference intensity ratio (RIR) method and was developed by Chung (JAC 19741975 [21, 22]). This internal standard method is based on eliminating matrix absorption effects. SED/EDX study was carried out on carbon-coated samples. Oxide percentages were determined by X-ray fluorescence.

Leaching: Leaching of elements were carried out using a modified version of method described by Finkelman EF 1990 [23] in that only bottom ash were leached by deionized water $\left(\mathrm{H}_{2} \mathrm{O}\right)$, ammonium acetate $\left(\mathrm{NH}_{4} \mathrm{OAc}\right)$, and hydrochloric acid $(\mathrm{HCl})$. The elemental content ( $\mathrm{As}, \mathrm{Cr}$ and $\mathrm{Ni}$ and $\mathrm{Pb}$ ) of leachates were determined using ICAPES.

\section{RESULTS AND DISCUSSION}

Bottom ash is a valuable product of coal combustion and it helps to retain some hazardous air pollutants and particles such as quartz and feldspar (Meij IT 2000 [14] Finkelman EF 1990 [23] Goodarzi Fuel 2006a [24]), thus, lowering their emission from stack. However, little attention is paid to the mineralogy and elemental composition of bottom ash as compared to ESP fly ash. The bottom ash in the present study is from seven pulverized coal power plants and a fluidized combustor. It consists of granular particles, which constitute bulk, and boiler slag, which is melted, glassy fragments and form minor part of samples. The fluidized combustor sample is composed entirely of granular particles.

\subsection{Variation of Quartz and Feldspar}

Table $\mathbf{1}$ is a comparison of quartz and feldspar content of bottom and ESP fly ash for same stations. The results indicate that quartz content of bottom ash produced from subbituminous coal is lower and that for bituminous coal and is higher compared to the corresponding ESP fly ash (Table 1). The feldspars are also higher in bottom ash compared to ESP fly ash (Table 1). In general, mineral matter such as quartz and feldspars remain unchanged during combustion due to their high melting point (quartz: $1710^{\circ} \mathrm{C}$ ) and their emission from stack is considered as possible human health hazards (Goodarzi Fuel 2006a [24] Puntis E 1980 [25]).

\subsection{Variation of Elements}

The bottom ash makes up approximately $25 \%$ of coal ash in power plants while the rest is captured as ESP fly ash and a minor amount $(0.5 \%)$ is emitted from stack as particulates (PM) (Goodarzi Fuel 2006b) [26]. The elements in coal and coal ashes are classified into various groups depending on their environmental impacts (Goodarzi IJCG 2006) [15]. For the bottom ash samples, five elements (As, $\mathrm{Cr}, \mathrm{Hg}$, $\mathrm{Ni}$ and $\mathrm{Pb}$ ) are designated as "toxic substances" under the terms of the Canadian Environmental Protection Act (CEPA 1995) [27]. The enrichment of elements in bottom ashes is an indication of redistribution of elements from the feed coals (Table 2) into both bottom (Table 3) and ESP fly ashes upon combustion (Meij KAP 1995) [16].

\subsection{Carbon and Sulphur Content}

The $\mathrm{C}$ and $\mathrm{S}$ contents of bottom ash range from 0.68 to $6.6 \mathrm{wt} \%$ and 0.03 to $10.72 \mathrm{wt} \%$, respectively (Table 3 ). The subbituminous coals have low $\mathrm{S}$ contents while bituminous coals have high $\mathrm{S}$ contents, except bituminous coal \#6 from western Canada, which has a low S content (Table 2), indicating that most of $S$ in station \#6 is captured by bottom ash in this sample. The fluidized bed ash has the highest $\mathrm{S}$ content in bottom ash samples (Table $\mathbf{3}$ ).

\subsubsection{Bottom Ash from Pulverised Coal}

These bottom ashes have lower concentrations of most of elements as compared to ESP fly ash (Goodarzi GSC 2002) [3] (Hower IJCG 1993) [17]. In general, the As content of bottom ash produced from high $\mathrm{S}$ feed coal is greater than 
Table 1. Percentage of Quartz and Feldspars in Granular Bottom Ash and ESP Fly Ash from Same Station

\begin{tabular}{|c|c|c|c|c|c|c|c|c|}
\hline Minerals & 1 & 2 & 3 & 4 & 5 & 6 & 7 & 8 \\
\hline \multicolumn{9}{|l|}{ Quartz, } \\
\hline Bottom ash & 9.20 & 15.0 & 8.40 & 10.30 & 12.50 & 8.15 & 1.30 & 2.20 \\
\hline ESP fly ash & 1.25 & 9.3 & 3.40 & 8.75 & N/D & 10.80 & 2.70 & 4.20 \\
\hline \multicolumn{9}{|l|}{ Feldspars } \\
\hline Bottom ash & 15.50 & 13.00 & 7.20 & 10.1 & 8.30 & & 1.70 & 11.2 \\
\hline ESP fly ash & 1.15 & & 0.10 & 0.30 & N/D & 0.25 & 2.50 & 1.10 \\
\hline
\end{tabular}

Table 2. Variation of Sulphur and Ash (wt \%) and Elements (mg/kg) in Canadian Feed Coals

\begin{tabular}{|c|c|c|c|c|c|c|c|c|}
\hline \multirow{2}{*}{ Elements } & \multicolumn{5}{|c|}{ Subbituminous } & \multicolumn{3}{|c|}{ Bituminous } \\
\hline & 1 & 2 & 3 & 4 & 5 & 6 & 7 & 8 \\
\hline$S^{*}$ & 0.51 & 0.73 & 0.36 & 0.37 & 0.32 & 0.66 & 2.90 & 3.60 \\
\hline As & 1.77 & 3.63 & 1.60 & 2.40 & 2.20 & 4.39 & 54.4 & 84.4 \\
\hline $\mathrm{Hg}$ & 0.03 & 0.06 & 0.03 & 0.04 & 0.05 & 0.19 & 0.20 & $\mathrm{~N} / \mathrm{D}^{* *}$ \\
\hline $\mathrm{Ni}$ & 5.30 & 5.67 & 6.30 & 7.30 & 4.30 & 15.20 & 8.30 & 13.6 \\
\hline $\mathrm{Pb}$ & 9.80 & 11.2 & 12.0 & 9.60 & 13.00 & 9.70 & 24.0 & 43.0 \\
\hline Ash & 15.3 & 16.6 & 22.2 & 18.80 & 20.4 & 27.4 & 29.4 & 33.2 \\
\hline
\end{tabular}

*Dry ash free; **N/D: Not determined.

Table 3. Variation of Carbon and Sulphur (wt \%) and Elements (mg/kg) in Canadian Bottom Ash

\begin{tabular}{|c|c|c|c|c|c|c|c|c|c|c|c|c|c|c|c|c|}
\hline \multirow{2}{*}{ Elements } & \multicolumn{10}{|c|}{ Subbituminous } & \multicolumn{6}{|c|}{ Bituminous } \\
\hline & 1 & $\mathbf{R E}^{*}$ & 2 & RE & 3 & $\mathbf{R E}$ & 4 & $\mathbf{R E}$ & 5 & RE & 6 & $\mathbf{R E}$ & 7 & $\mathbf{R E}$ & 8 & $\mathbf{R E}$ \\
\hline $\mathrm{C}$ & 0.19 & $\mathrm{~N} / \mathrm{D}^{\#}$ & 6.62 & $\mathrm{~N} / \mathrm{D}$ & 0.44 & N/D & 1.47 & N/D & 1.14 & $\mathrm{~N} / \mathrm{D}$ & 0.55 & N/D & 5.80 & N/D & 5.30 & N/D \\
\hline $\mathrm{S}^{* *}$ & 0.03 & 0.01 & 0.15 & 0.03 & 0.04 & 0.02 & 0.02 & 0.00 & 2.32 & 1.48 & 0.05 & 0.02 & 0.19 & 0.02 & 10.7 & 1.00 \\
\hline As & 3.63 & 0.31 & 6.00 & 0.27 & 1.60 & 0.22 & 3.70 & 0.29 & 1.70 & 0.16 & 0.30 & 0.02 & 34.0 & 0.18 & 445 & 1.75 \\
\hline $\mathrm{Cr}$ & 28.0 & 0.96 & 156 & 0.88 & 29.0 & 0.55 & 54.0 & 0.76 & 43.0 & 1.46 & 344 & 1.82 & 45.0 & 1.28 & 22.0 & 0.74 \\
\hline $\mathrm{Hg}$ & 0.01 & 0.05 & 0.02 & 0.06 & 0.01 & 0.07 & 0.01 & 0.05 & 0.01 & 0.04 & 0.05 & 0.07 & 0.02 & 0.04 & 0.08 & N/D \# \\
\hline $\mathrm{Ni}$ & 30.3 & 0.87 & 22.3 & 0.65 & 23.0 & 0.81 & 30.0 & 0.77 & 21.0 & 1.00 & 39.6 & 0.71 & 44.3 & 1.57 & 15.7 & 0.38 \\
\hline $\mathrm{Pb}$ & 17.7 & 0.28 & 11.3 & 0.17 & 24.0 & 0.44 & 8.70 & 0.17 & 4.30 & 0.07 & 6.33 & 0.18 & 12.7 & 0.16 & 16.0 & 0.12 \\
\hline
\end{tabular}

*RE: Relative Enrichment Index; **Dry ash free; \#N/D:Not Determined.

those produced from low $\mathrm{S}$ feed coals (Tables $\mathbf{2}$ and $\mathbf{3}$ ) indicating that As and $\mathrm{S}$ have similar source (sulphides, such as pyrite) and some of As of feed coals is captured by bottom ash; therefore, prevented from being emitted to the environment.
Most of the elements in the bottom ashes have RE factors less than 0.7 indicating that they are not enriched in the bottom ash as compared to the feed coals (Tables $\mathbf{2}$ and $\mathbf{3}$ ). There are differences in elemental contents of granular particles of bottom ash as compared to the glassy melted fragments. Generally, the granular bottom ash particles have 
higher concentrations of some elements as compared to the glassy slag for pulverized coal fired power plants (Table 4); for example, the concentrations of $\mathrm{As}$ and $\mathrm{Ca}$ are three times higher for bottom ash particles compared to the slag (Table 4).

\subsubsection{Bottom Ash from Fluidized Bed}

The bottom ash from fluidized combustor has the highest content of As than that in ESP fly ash, which associated with high $\mathrm{S}$ in this ash (Table 3 ), indicating that the lime $(\mathrm{CaO})$ in the system has successfully removed the As and $\mathrm{S}$ from the system, possibly through the reaction between $\mathrm{As}$ and $\mathrm{CaO}$ $\left(\mathrm{As}_{2} \mathrm{O}_{3}\right)$ or by iron oxides (Gutlberlet VGBK 1988) [28]. This is the only bottom ash that has a higher concentration of As than its corresponding ESP fly ash (Table 4) indicating that this bottom ash was able to capture high percentage of As due to the presence of $\mathrm{CaO}$.

There is also similar relation to that of pulverized coal bottom ash between the particulate and glassy melted for this sample (Table 4). The concentration of As is 3.3 times greater than the larger glassy particles in smaller granular ash (Table 4). What is important is that the glassy bottom ash has higher concentration of metallic elements such as $\mathrm{Cr}, \mathrm{Ni}$, and $\mathrm{Pb}$ (Table 4), which is related to high concentration of metallic particle in this ash (Fig. 1).

\section{SPECIATION OF ELEMENTS IN BOTTOM ASH}

\subsection{Arsenic}

The toxicity of As depends on its chemical form and decreases in the order of $\mathrm{As}^{3+}>\mathrm{As}^{5+}>$ organo-arsenic (Fergusson PP 1990) [29] and does not serve any known useful biological function (Ashby PCEC 1993) [30]. It is usually ingested as arsenate $\mathrm{As}^{5+}$, then, it is reduced in the body to the more toxic form of $\mathrm{As}^{3+}$, where it can interfere with enzymes and results in a highly toxic effect in the body (Ashby PCEC 1993) [30] (Harte UCP 1991) [31]. Arsenic at higher concentrations can cause liver and kidney damage (Fergusson PP 1990) [29]. Therefore, it is one of the elements that is listed as "Toxic substance" by EPRI (EPRI 1994) [12] and CEPA (EC 1995) [27] as carcinogenic health risk. The adverse effect of arsenic "arsenosis" is sometimes evident when coal with high As contents is burnt such those documented in Czechoslovakia and China (Swaine B 1990) [32] (Finkelman IJCG 2002) [33]. Arsenic in coal is generally associated with pyrite, most likely in solid solution (Swaine B 1990 [32] Finkelman IJCG 2002) [33]) Goodarzi IJCG 1993 [34].

The arsenic content of bottom ash increases with increasing sulphur content and the highest arsenic is found in the bottom ash (\#7) from the fluidized bed combustor. In addition, As is greater in granular ash than in the fused glassy type in this bottom ash (Table 4). The granular bottom ash contains metallic-like particles of hematite and magnetite, which may provide surface for deposition of arsenic (Fig. 1). In general, the arsenic content of the bottom ash is much lower than that of the corresponding ESP fly ash (1.75-54.0 $\mathrm{mg} / \mathrm{kg}$ ), sometimes by a factor of 10 . This is consistent with arsenic being a class II element (Meij KAP 2005) [16]. However, the relationship of bottom/ESP ESP fly ash established for pulverized coal-fired power plant (\#1-7) does not appear to apply to ash from the fluidized bed combustor (\#8), where the concentration of As in ESP fly ash is 146 $\mathrm{mg} / \mathrm{kg}$ and for bottom ash is $445 \mathrm{mg} / \mathrm{kg}$ (Table 3). Arsenic in bottom ash from low sulphur subbituminous coal and high sulphur bituminous coal is not leachable by water and ammonium acetate $\left(\mathrm{NH}_{4} \mathrm{OAc}\right)$. Arsenic is only leached by $\mathrm{HCl}$ at $35 \%$ and $37 \%$ for subbituminous, $24 \%$ for bituminous ashes and $74 \%$ from fluidized bed bottom ash (Table 5).

\subsubsection{Speciation of As}

Spectral data for the two major As oxidation states, $\mathrm{As}^{3+}$ and $\mathrm{As}^{5+}$ for a high pyrite coal used as standard are shown in Fig. (1). The XANES spectra of bottom ash \#1-4 are similar and have greater signal/noise ratio (Fig. 2).

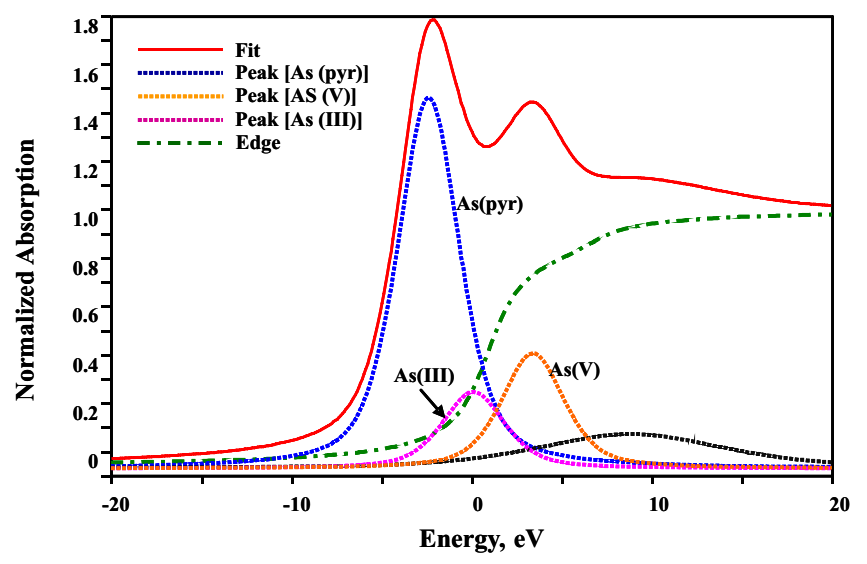

Fig. (1). The least square fitting of the XANES spectra for milled coal with high pyrite content. Peaks denoted by "A" and "P" arise from arsenic as arsenate $\left(\mathrm{As}^{5+}\right)$ and as As in pyrite (substitutes for sulphur in pyrite i.e. $\mathrm{As}_{2}{ }^{2+}$ for $\mathrm{S}_{2}{ }^{2+}$ )

However, in the spectra of three-bottom ash \#1-3, a fraction of the arsenic must be present in more than one oxidation states in order to account for the weak broad shoulder at about $-0.5-1.5 \mathrm{eV}$ (Fig. 1). For these samples, the $\mathrm{As}^{3+}$ content varies from $<10 \%$ to as much as $20 \%$, while the $\mathrm{As}^{5+}$ content varies inversely. However, for bottom ash \#4, the low-energy shoulder is broad and the position of the peak at about $-1.4 \mathrm{eV}$ is intermediate between that for arsenic associated with pyrite $(-2.25 \mathrm{eV})$ and $\mathrm{As}^{3+}$ in oxygen coordination $(0.0 \mathrm{eV})$ (Fig. 2); indicating that about $5-10 \%$ of the arsenic is in association with $\mathrm{As}^{3+}$ and $80-90 \%$ as $\mathrm{As}^{5+}$ and 5$10 \%$ as pyrite. The arsenic spectrum of the bottom ash for low sulphur bituminous coal (\#5) is very weak and this indicates that virtually all the arsenic is volatilized during combustion and very little is incorporated into the bottom ash (Fig. 1). This is confirmed by the very low RE factor of 0.02 obtained for As in this bottom ash (Table 3). The feed coal 6 and 7 have similar and high sulphur coal (Table 1), but the speciation of As in bottom ash \#6 is very different to that \#7 (Fig. 1). This is due to the bottom \#6 is from pulverized coal and that of \#7 from fluidized combustion. The arsenic species in the bottom ash from fluidized combustion is mostly $(85-90 \%)$ in the form of $\mathrm{As}^{5+}$ with $10-15 \%$ of the arsenic as $\mathrm{As}^{3+}$ (Fig. 2). In contrast, the arsenic XANES spectrum of the bottom-ash \#7 produced from fluidized combustor is almost entirely $\mathrm{As}^{5+}$, a small feature at about $15 \mathrm{eV}$, which is indicative of the formation of crystalline arsenates in this 
sample (Fig. 1). Possibly due presences of calcium arsenate/sulphate (Huggins EF 1994) [35] (Huffman JFPT 1994) [36]' due to use of limestone in the fluidized-bed combustor, which transformed the pyrite to the arsenic compound.

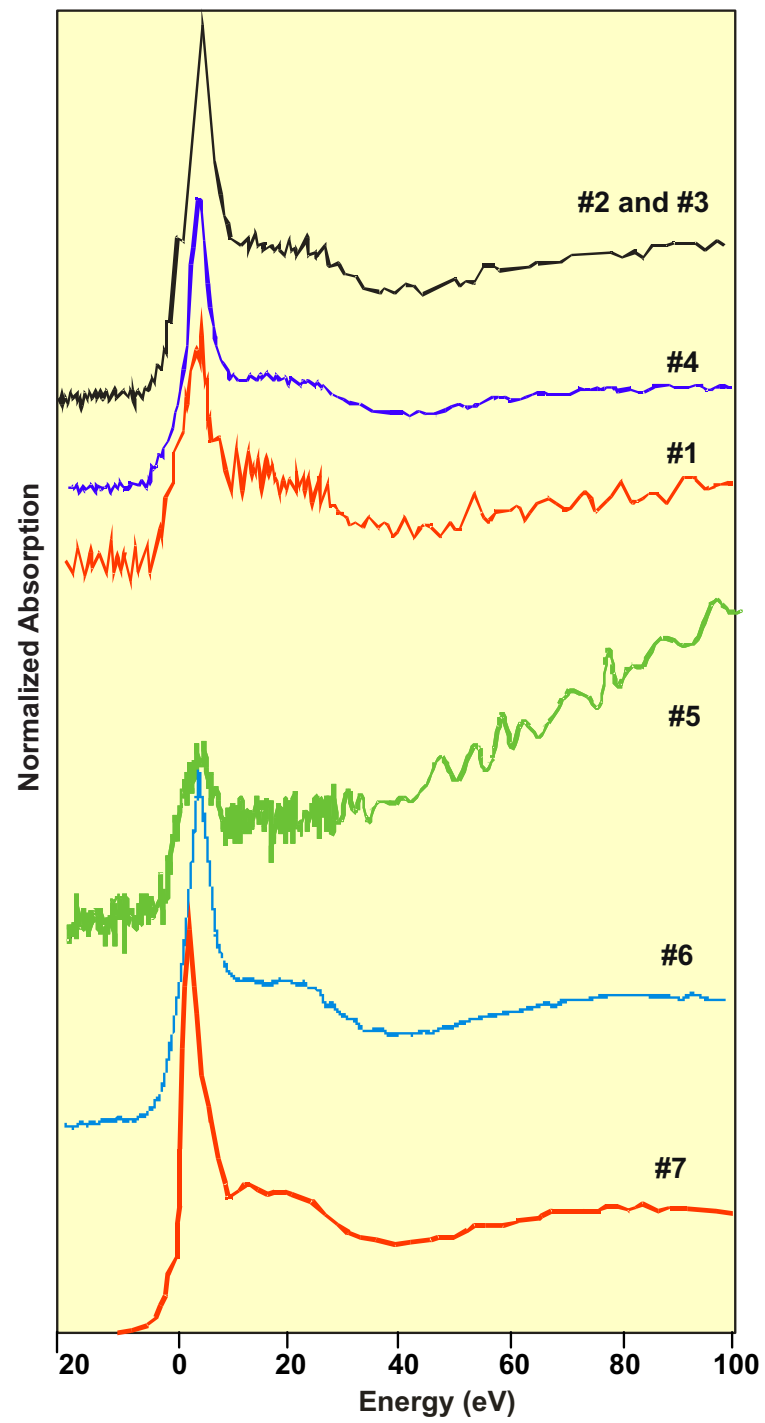

Fig. (2). Arsenic K-edge XANES spectra of bottom ash\#1-4, produced by pulverized subbituminous coal combustion, bottom ash\#5 from low sulphur and \#6 and \#7 from high sulphur bituminous coal. Bottom ash\#5 and \#6 are from pulverized coal combustion, while \#7 is from a fluidized bed combustor.

\subsection{Chromium}

Chromium naturally occurs as three stable forms of, $\mathrm{Cr}^{0}$, $\mathrm{Cr}^{3+}$, and $\mathrm{Cr}^{6+}$, with $\mathrm{Cr}^{3+}$ being the most abundant (Harte UCP 1991) [31]. Chromium as $\mathrm{Cr}^{3+}$ is essential for carbohydrate metabolism and chromium deficiency may cause diabetes whereas $\mathrm{Cr}^{6+}$ is carcinogenic (Beliles M 1975 [37] Anderson STE 1981 [38]. The adverse effects of $\mathrm{Cr}^{6+}$ is also short lived and it rapidly changes to $\mathrm{Cr}^{3+}$ form (Harte UCP 1991) [31]. Chromium also does not bioaccumulate in the food chain (Harte UCP 1991) [31]. However, Cr can cause lung cancer, when inhaled as $\mathrm{Cr}^{+6}$ (chromates) as fine particulates (Piperno ACS 1975) [39]. Chromium in these bot- tom ashes is low as compared to coal and ESP fly ash, which is evident by its low RE (Table 1). Chromium in bottom ash from low sulphur subbituminous coals and high sulphur bituminous coal is not leachable by water and ammonium acetate $\left(\mathrm{NH}_{4} \mathrm{OAc}\right)$, and only leached by $\mathrm{HCl}$ at $12 \%$ and $96 \%$ for subbituminous and $12 \%$ for bituminous (Table 5). Bottom ash from fluidized bed has 17.3 leachable $\mathrm{Cr}$ (Table 5).

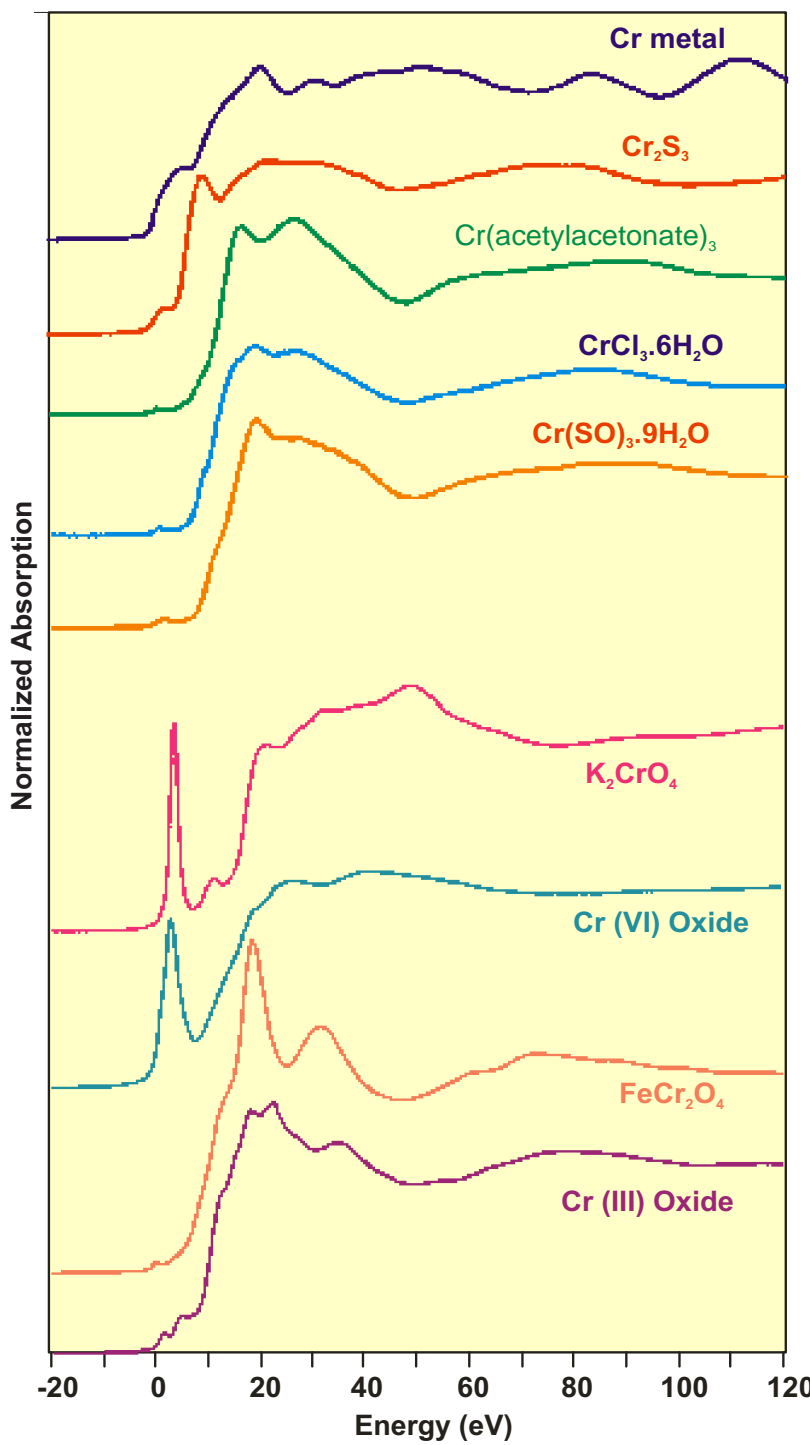

Fig. (3). Chromium XANES spectra of various standard materials; top five indicates special shapes for the metallic and sulfide chromium compounds and those compounds in which chromium is occasionally coordinated by oxygen whereas bottom four indicates two $\mathrm{Cr}^{3+}$ oxide minerals and for two $\mathrm{Cr}^{6+}$ oxide compounds. Note the prominent pre-edge peak at about $2 \mathrm{eV}$ that is highly characteristics of hexavalent chromium.

\subsubsection{Speciation of Chromium}

The standards used for determination of species of $\mathrm{Cr}$ consists of compounds found in nature such as metallic and sulphide chromium, which have different XANES spectral than the compounds associated with oxygen with two major $\mathrm{Cr}$ oxidation states i.e. $\mathrm{Cr}^{6+}$ and $\mathrm{Cr}^{3+}$ (Fig. 3). There is always a prominent pre-edge peak $\cong 4-5 \mathrm{eV}$ associated with com- 
pound containing $\mathrm{Cr}^{6+}$, where as $\mathrm{Cr}^{3+}$ compounds does not display such peaks (Fig. 3). The Cr XANES spectra of the bottom ash samples from stations 1 to 4 do not show any evidence of a peak at 4-5 eV that can be attributed to $\mathrm{Cr}^{6+}$ (Fig. 4); therefore, their $\mathrm{Cr}$ is mostly (>95\%) $\mathrm{Cr}^{3+}$ that is in association with aluminosilicate phases such as glass. The chromium XANES spectrum in this group of bottom ash often show broader peaks, which is dissimilar to the feed coal, indicating the transformation of $\mathrm{Cr}^{3+} /$ illite in coal to a range of distorted sites in the aluminosilicate (glass) matrix in the bottom ash. Chromium spectrum in sample \#6 show a slight prominent pre-edge feature than other samples, indicating a minor presence of $\mathrm{Cr}^{6+}$ (Fig. 4). The spectrum of $\mathrm{Cr}$ for bottom ash \#6 is similar to that for \# 1 and consists mostly of the $\mathrm{Cr}^{3+}$ oxidation state (Fig. 4). However, this sample is produced from a coal with high pyrite/sulfur content and relatively featureless and flat spectra is observed that is more consistent with sulfide and metallic forms of chromium. The $\mathrm{Cr}$ spectrum for the bottom ash from fluidized bed combustor is quite weak and is entirely $\mathrm{Cr}^{3+}$.

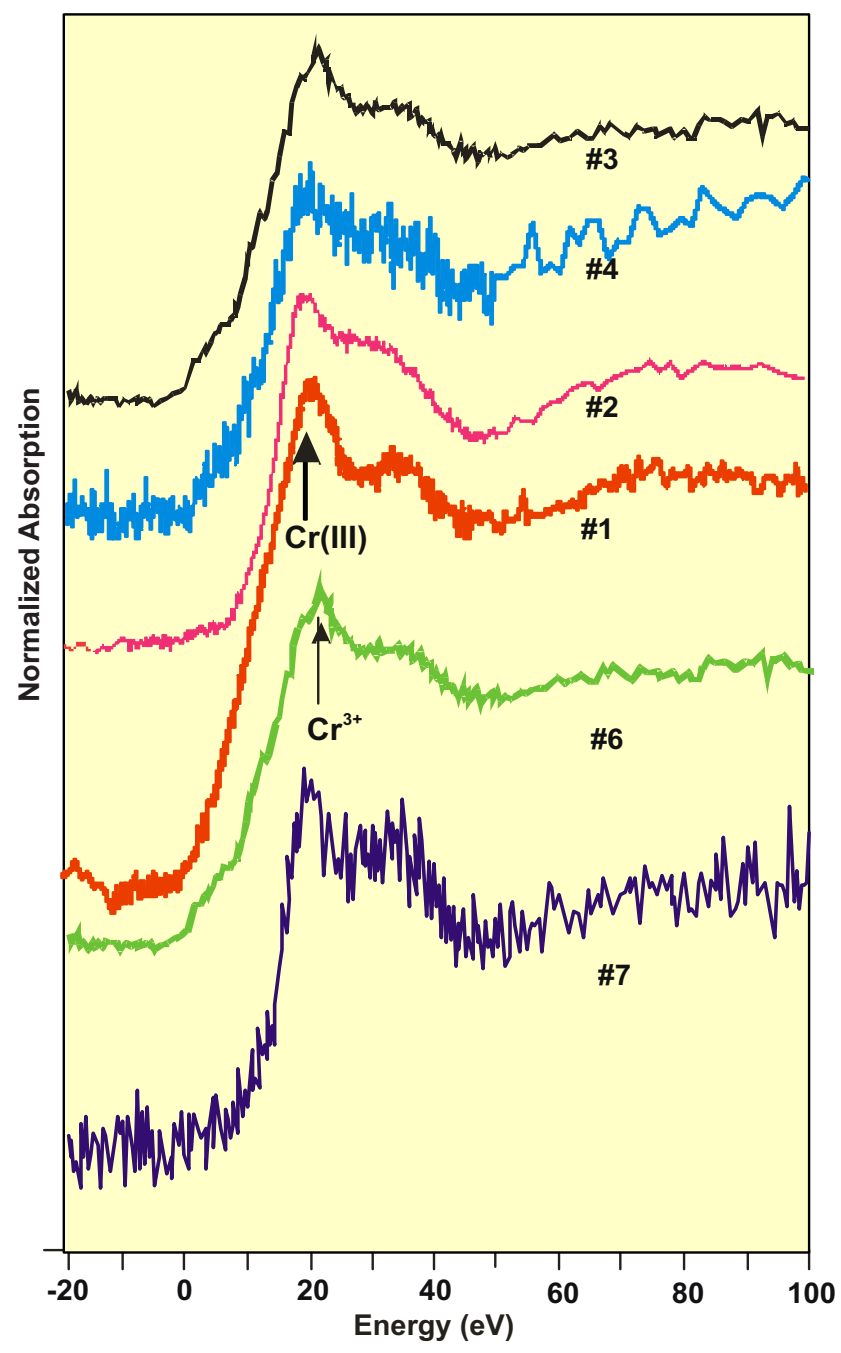

Fig. (4). Comparison of chromium XANES spectra of bottom ash from coal-fired power plants, subbituminous feed coals (\#1, 2, 3, and 4), bituminous coal (\#6), and fluidized bed combustor (\#7). Zero point of energy corresponds to $5989 \mathrm{eV}$.

\subsection{Mercury}

Mercury in coal is a volatile element and is mostly emitted due to combustion from stack and partially captures by carbon in ESP fly ash (Goodarzi IJCG 2004, 2006 [40, 41] JEM 2004 [42] Hower EF 2000 [43]). Mercury has higher priority than any other elements due to its inherent toxic effects on humans and wildlife (Fergusson PP 1990 [29] Moore AP 1976 [44] USEPA 1997c [45]. The adverse health and environmental effects of $\mathrm{Hg}$ is mostly associated with organic $\mathrm{Hg}$ compounds such as methyl mercury, which is a potent neurotoxin (Fergusson PP 1990 [29] Moore AP 1976 [44] USEPA 1997c [45] WHO 1996 [46]. Most of mercury in soil, sediments, water, plants, and animals is in the forms of inorganic $\mathrm{Hg}$ salts and organic forms of $\mathrm{Hg}$, primarily methyl mercury (Ashby RSC 1993 [30] USEPA 1997a, $1997 b[47,48]$.

In general, the total amount of mercury in the environment is not changed since $\mathrm{Hg}$ is an element that is part of the earth system (Lindberg EST 1998) [49] and cycles because of natural and geogenic activities (Rassmussen GSC 1996) [50]. However, the redistribution of mercury from geogenic sources into the air, water, and topsoil have been influenced by anthropogenic activities such coal burning, where it may more readily enter the food chain (Goodarzi GSC 2002, JEM $2001[3,51]$. Mercury in bottom ash (Table $\mathbf{3}$ ) has a very low $\mathrm{Hg}$ content compared to feed coal and ESP fly ash (Goodarzi GSC 2002) [3].

\subsubsection{Role of Bottom Ash in Mass Balance of Mercury}

The role of bottom ash in capture of mercury during the combustion of coal is not well understood. This is due to low Hg content of bottom ash (Hower JCQ 1993 [5] Goodarzi JEM 2004 [42]). Mercury is mostly captured by carbon in ESP ash (Goodarzi IJCG 2005 [41] Hower EF 2000) [43]. The relation between carbon and mercury in bottom ash is not same as ESP fly ash, since an increase of carbon in ESP fly ash particularly from subbituminous to high volatile bituminous coal is generally accompanied by increase in $\mathrm{Hg}$ content of ESP fly ash (Goodarzi Fuel 2007) [52]. However, in bottom ash such a relation is not evident (Table 6). This is clearly demonstrated by the bottom ash from Canadian power plants having carbon content of 0.11-16.5\% (Table 6). The data present in this table indicates that bottom ash contribute between $1-16 \% \mathrm{Hg}$ captured for power plants that are equipped with cold side ESP (Table 7); but for power plants equipped with hot side ESP, the capture of $\mathrm{Hg}$ by both ash is low and almost equal (Table 7).

\subsection{Nickel}

Nickel is an element that in small amount is beneficial to health (Harte UCP 1991) [31] some of its compounds are considered as possible human carcinogens (IARC 1980) [53]. The carcinogenic compounds of nickel consists of sub sulphides $\left(\mathrm{Ni}_{1+\mathrm{x}} \mathrm{S}\right.$, where $\mathrm{x}=0$ to 0.5$)$ and nickel tetracarbonyl [Ni (CO) 4 ] (Beliles M 1975 [37] Linton RSC 1993 [54]). Another toxic form of Ni is Nickel carbonyl, which forms due to reaction between CO and Ni (Beliles M 1975 [37] Linton RSC 1993 [54]).

The oxidation state of Nickel carbonyl is (0) and for nickel sulphide it is (II). Nickel has a detrimental effect on the health of mammals in particulate form (Fergusson PP 
Table 4. Variation of Elements (mg/kg) in Particulate Bottom Ash and Slag for Stations \#1 and Large and Small Particles for Station \#8 and their Corresponding ESP Fly Ash (mg/kg)

\begin{tabular}{|c|c|c|c|c|c|c|}
\hline \multirow[b]{2}{*}{ Elements } & \multicolumn{3}{|c|}{ Pulverized Coal-Fired \#1 } & \multicolumn{3}{|c|}{ Fluidized Bed Combustor \#8 } \\
\hline & \multicolumn{2}{|c|}{ Bottom Ash } & ESP Fly Ash & \multicolumn{2}{|c|}{ Bottom Ash } & ESP Fly Ash \\
\hline As & 3.6 & 1.1 & 20.7 & 445 & 12.7 & 146 \\
\hline $\mathrm{Ni}$ & 30.3 & 27.7 & 38.8 & 15.7 & 55.3 & 32.0 \\
\hline $\mathrm{Pb}$ & 17.7 & 10.8 & 48.7 & 16.0 & 92.2 & 177 \\
\hline $\mathrm{Ca}$ & 52200 & 45555 & 60000 & 376000 & 36300 & 199000 \\
\hline
\end{tabular}

*N/D: Not determined.

Table 5. Percent of Elements Leached from Bottom Ash by Water, Ammonium Acetate, and HCl

\begin{tabular}{|c|c|c|c|c|c|c|c|c|}
\hline Elements & $\begin{array}{c}1 \\
\mathrm{H}_{2} \mathrm{O} \& \mathrm{NH}_{4} \mathrm{OAc}\end{array}$ & $\mathrm{HCl}$ & $\begin{array}{c}3 \\
\mathrm{H}_{2} \mathrm{O} \& \mathrm{NH}_{4} \mathrm{OAc}\end{array}$ & $\mathrm{HCl}$ & $\begin{array}{c}7 \\
\mathrm{H}_{2} \mathrm{O} \& \mathrm{NH}_{4} \mathrm{OAc}\end{array}$ & $\mathrm{HCl}$ & $\begin{array}{c}8 \\
\mathrm{H}_{2} \mathrm{O} \& \mathrm{NH}_{4} \mathrm{OAc}\end{array}$ & HCl \\
\hline As & 3 & 35 & 0 & 37 & 0 & 24 & 1 & 74 \\
\hline $\mathrm{Cr}$ & 0 & 23 & 0 & 96 & 0 & 12 & 0 & 17 \\
\hline $\mathrm{Ni}$ & 0 & 19 & 0 & 74 & 2 & 15 & 0 & 1 \\
\hline
\end{tabular}

Table 6. Role of Bottom Ash in Mass Balance of Mercury for Some of Canadian Power Plants Using Subbituminous Coals

\begin{tabular}{|c|c|c|c|c|c|c|}
\hline Power Plants & \#1 & $\# 2$ & $\# 3^{*}$ & $\# 4$ & $\# 5$ & $\# 6^{* *}$ \\
\hline Inlet mercury mass flow rate $(\mathrm{g} / \mathrm{h})$ & 9.47 & 19.52 & 20.48 & 26.15 & 29.44 & 7.1 \\
\hline Dry base carbon-free ash mass flow rate $(\mathrm{Mg} / \mathrm{h})$ & 23.31 & 36.45 & 103.7 & 79.8 & 94.7 & 26.71 \\
\hline Dry Base carbon content of bottom ash (\%) & 2.89 & 6.25 & 2.93 & 2.32 & 16.5 & 1.22 \\
\hline Total estimated ash flow, including carbon $(\mathrm{mg} / \mathrm{h})$ & 23.43 & 50.3 & 105 & 81.99 & 99.53 & 28.46 \\
\hline Bottom ash mass flow rate $(\mathrm{mg} / \mathrm{h})$, at $25 \%$ of total ash & 5.86 & 14.39 & $42 *$ & 20.49 & 24.88 & 6.76 \\
\hline Mercury released in the bottom ash $(\mathrm{g} / \mathrm{h})$ & 0.12 & 0.20 & 0.17 & 0.07 & 0.27 & 0.12 \\
\hline Total outlet mercury mass flow rate in ash $(\mathrm{g} / \mathrm{h})$ & 0.76 & 2.66 & 8.55 & 9.87 & 18.09 & 0.25 \\
\hline Mercury emission rate in flue $\mathrm{gas}(\mathrm{g} / \mathrm{h})$ & 10.89 & 15.66 & 12.74 & 12.84 & 12.74 & 6.95 \\
\hline Fraction found in the ash (\%) & 6.17 & 13.55 & 40.3 & 42.45 & 57.58 & 3.33 \\
\hline Fraction found in the flue gas $(\%)$ & 93.83 & 86.45 & 59.7 & 57.55 & 42.42 & 96.67 \\
\hline
\end{tabular}

*Station \#3 has split of $40 \%$ bottom ash and $60 \%$ ESP ash.

**This power plant is equipped with hot side ESP. 
Table 7. Role of Bottom Ash in Capture of Mercury in Some Canadian Power Plants Using Subituminous Coals

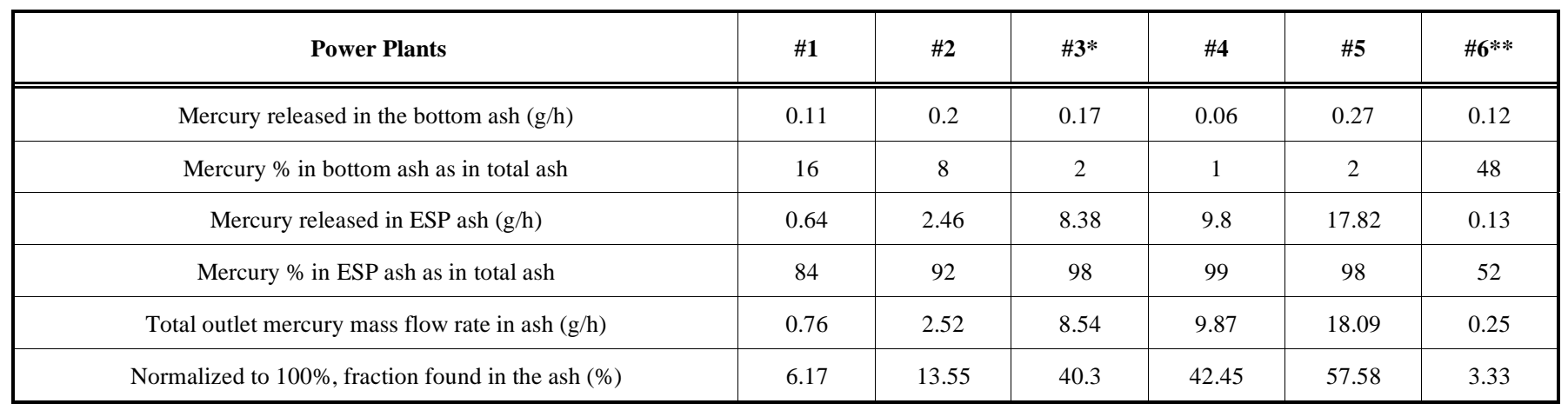

*Station \#3 assumes a split of $40 \%$ bottom ash and $60 \%$ ESP ash.

**This power plant is equipped with hot side ESP.

1990) [29]. Nickel in bottom ash from low sulphur subbituminous coal and high sulphur bituminous coal is not leachable by water and ammonium acetate $\left(\mathrm{NH}_{4} \mathrm{OAc}\right)$, and only leached by $\mathrm{HCl}$ at $19 \%$ and $74 \%$, for subbituminous and $15 \%$ for bituminous coal. Bottom ash from fluidized bed has very little leachable $\mathrm{Ni}$ (Table 5).

\subsubsection{Speciation of Nickel}

The standard for Ni is shown in Fig. (5), which consists of the metallic, sulphide of $\mathrm{Ni}$ and compounds in which $\mathrm{Ni}$ is coordinated with oxygen (Fig. 5). Nickel is designated as a "toxic substance" by the Canadian Environmental Protection Agency (CEPA 1995) [27]. Therefore, it is necessary to determine the speciation of $\mathrm{Ni}$ in any products associated with anthropogenic activities such generation of energy from coal-fired power plants and residual oil combustion (Goodarzi JEM 2004 [18].

Another toxic Ni compounds is Nickel carbonyl, which forms due to reaction between $\mathrm{CO}$ and $\mathrm{Ni}$. The subbituminous coals produced bottom ash that show a fairly strong peak with $\mathrm{Ni}^{2+}$ in coordination predominantly with oxygen anions, at about $20 \mathrm{eV}$ (Fig. 6). The nickel for the bottom ash samples \#1, \#3, and \#4 have higher Ni contents (23 to 30 $\mathrm{mg} / \mathrm{kg}$ ) and/or lower iron contents and better quality XANES spectra. The Ni XANES spectra for bottom ash produced from the bituminous feed coals (Fig. 6) is also showing a strong peak at about $20 \mathrm{eV}$, consistent, indicating of $\mathrm{Ni}^{2+}$ in coordination predominantly with oxygen (Fig. 6). The spectra for bottom ash produced from fluidized bed combustor are very weak (Fig. 6). Nickel in these bottom ash samples appears to be in an oxygen environment similar to that reported for silicate glasses and carcinogenic Ni sulphides are not present in these bottom ashes.

\subsection{Lead}

Lead is naturally occurring mineral and is widespread in soil, water, and air. Lead is associated with sulphides in coal (Finkelman KAP 1995) [55]. Its effects on human are both physiological and neurological (Fergusson PP 1990) [29]. Its health effects are severe even at low doses and mostly on brain and blood forming system (Harte UCP 1991) [31]. It may cause irreversible brain damage. In general, $\mathrm{Pb}$ is a volatile element and does not concentrate in bottom ash (Goodarzi GSC 2002) [3] as indicated by low RE value (Ta- ble 3). In addition, it is not leached by water, ammonium acetate $\left(\mathrm{NH}_{4} \mathrm{OAc}\right)$ and only $23 \%$ of $\mathrm{Pb}$ is leached by $\mathrm{HCl}$ from subbituminous and $7 \%$ from bituminous coal (Table 5).

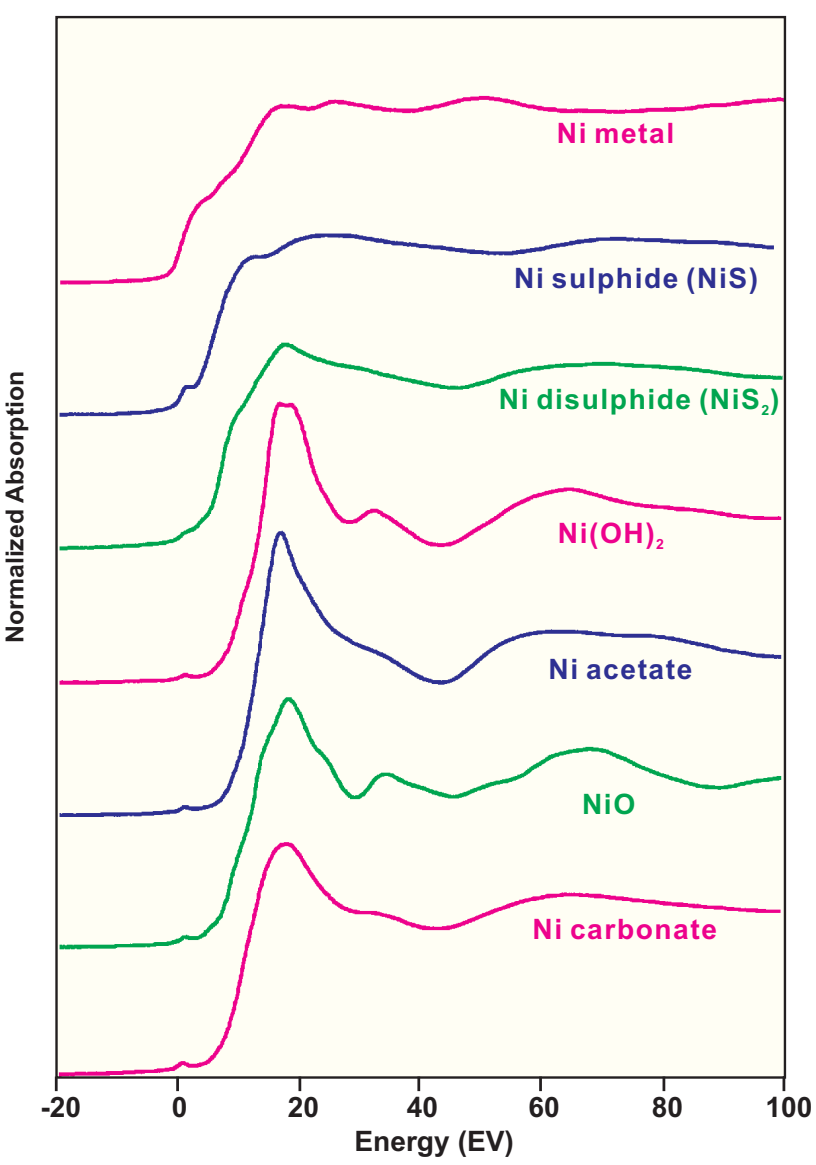

Fig. (5). Nickel XANES spectra of various standard materials. Note how the overall spectral shapes for the metallic and sulphide nickel compounds differ from those compounds in which nickel is coordinated with oxygen. The zero-point of energy for these and subsequent Ni XANES spectra corresponds to $8333 \mathrm{eV}$. 


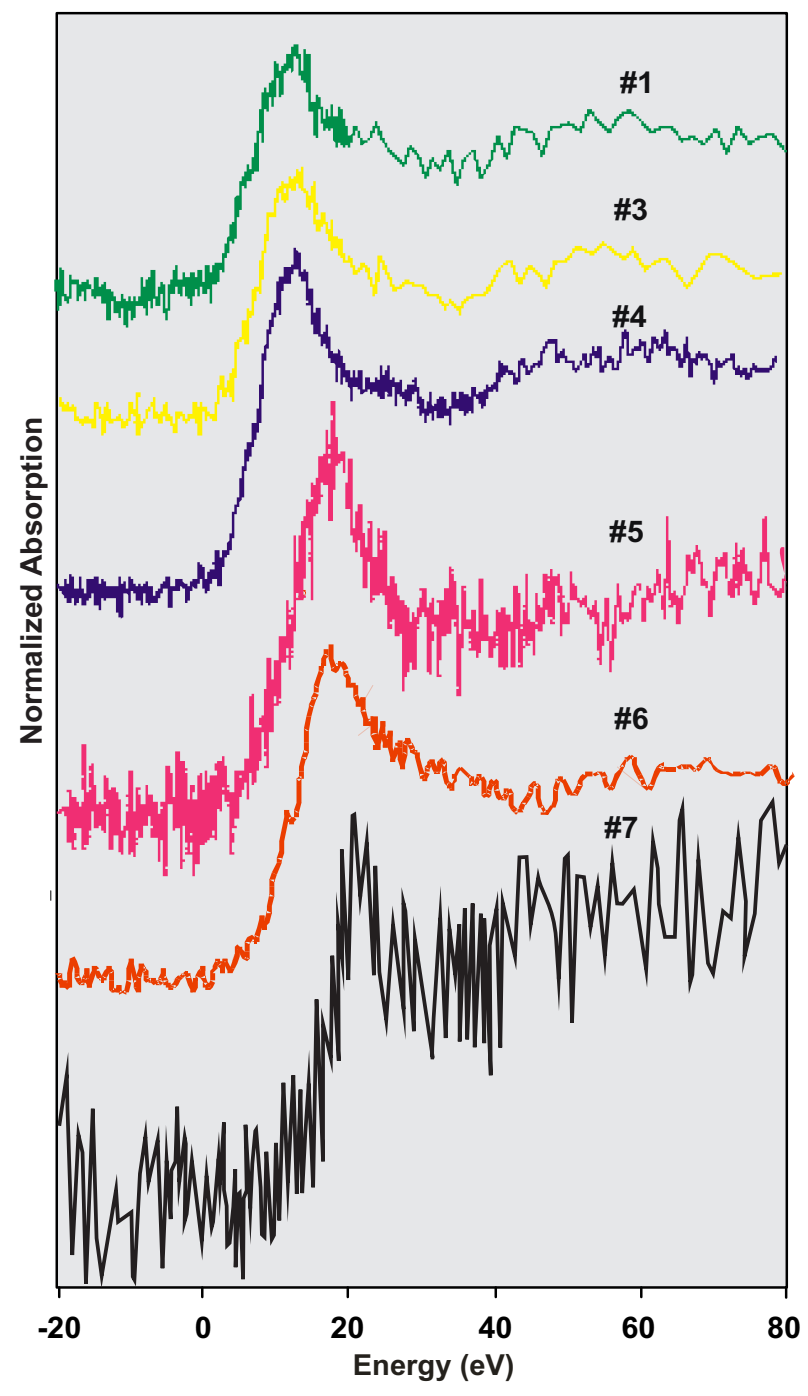

Fig. (6). Ni XANES spectra of bottom ash from combustion of bituminous feed coal \#1-7

\section{ENVIRONMENTAL ASSESSMENT}

The present results indicate that feldspars and quartz of feed coal are mostly captured by bottom ash, particularly in bituminous coal (Table 1), this is important since both emitted quartz and feldspars particles (PM) are considered as possible occupational hazards.

The environmental impact of the $\mathrm{As}, \mathrm{Cr}, \mathrm{Hg}, \mathrm{Ni}$ and $\mathrm{Pb}$ is low and they are in form of; non toxic $\mathrm{As}^{+3}$, mostly beneficial $\mathrm{Cr}^{3+}$, and non carcinogenic $\mathrm{Ni}^{2+}$ in coordination predominantly with oxygen. Mercury and $\mathrm{Pb}$ are low and have very little environmental impact.

Arsenic, $\mathrm{Cr}, \mathrm{Ni}$ and $\mathrm{Pb}$ become only mobile under strong acidic condition, which generally is not occur naturally and in the bottom ash storage facilities. Therefore, the environmental impact of Bottom ash is considered very low.

\section{ACKNOWLEDGEMENTS}

The author thanks the management, scientists, and technologists of the coal-fired utilities from Alberta for their help with sampling and valuable advice. Thanks are also due to the following laboratories and scientists for help in sampling, analyzing, and presentation of results: Becquerel Laboratories Inc. in Mississauga, Ontario; and GWIL Industries of Calgary, Alberta for analytical work. The Federal InterDepartment Program on Energy Research and Development (PERD) and the Canadian coal-fired power plants funded this research jointly. The authors also acknowledge the help of Mr. J. Reyes in preparation of the paper.

\section{REFERENCES}

[1] Clarke LB, Sloss LL. Trace elements- emissions from coal combustion and gasification. IEA Coal Research, London ICEACR, 1992; 49: p. 111

[2] Cloke M, Lester, E. Characterization of coal for combustion using petrographic analysis. Fuel 1994; 73: 315-20.

[3] Goodarzi F, Peel WP, Brown J, Charland JP, Huggins F, Percival J. Elemental concentration and speciation, polyaromatic hydrocarbons and mineralogical characteristics of milled-coal and ashes from the Unit \#5 at Battle River Station. Bull Geol Surv Canada 2002; 570: p. 148

[4] Helle S, Gordon A, Alfaro G, Garcia X, Ulloa C. Coal blend combustion: link between unburned carbon in ESP fly ash and maceral data. Fuel Proc Tech 2003; 80: 209-23.

[5] Stultz CR, Kitto JB. Steam - Its Generation and Use, Babcock and Wilcox Company, Barberton, Ohio, 40 ${ }^{\text {th }}$ ed., 1992: p. 980.

[6] Hecht NL, Duvall DS. Characterization and Utilization of Municipal and Utility Sludges and Ashes: Utility Coal Ash. National Environmental Research Centres, U.S. Environmental Protection Agency 1975; 3: p. 75 .

[7] Moulton LK. "Bottom Ash and Boiler Slag," Proceedings of the Third International Ash Utilization Symposium. U.S. Bureau of Mines, Inf. Cir. 8640, Washington, DC, 1973; pp. 148-69.

[8] ASTM E1861-97. Standard Guide for Use of Coal Combustion ByProducts in Structural Fills, American Society for Testing and Materials, West Conshohocken, Pennsylvania 1997.

[9] Lovell CW, Ke T-C, Huang W-H, Lovell JE. Bottom ash as highway material, Presented at the 70th Ann. Meet. Trans.Res. Board: Washington, D.C. 1991.

[10] Moulton LK, Seals, RK, Anderson DA. Utilization of ash from coal burning power plants in highway construction. Transportation Research Record No. 430, Washington, DC, 1973; pp. 26-39.

[11] Swaine DL. The Formation, Composition, and Utilization of Flyash. In: Swaine DJ, Goodarzi F, Eds. Environmental aspects of trace elements in coal. Dordrecht, the Netherlands: Kluwer Academic Publishers, 1995; 2: pp. 204-62

[12] Electric Research Institute (EPRI), Electric utility traces substances synthesis report. Synthesis Report. Electric Power Research Institute, Palo Alto: California1994; vol. 1: pp. 1-56.

[13] American society for testing and materials, standards ASTM, 1978; 26: D 3176-74, p.390, D 62: D1757-77, p.264.

[14] Meij R, Siep N, Winkel H. The occurance of Quatrz in coal ESP fly ash particles. Inhal Toxicol 2000; 12 (Suppl 3): 109-12.

[15] Goodarzi F. Assessment of elemental content of feed coal, combustion residues, and stack emitted materials for a Canadian pulverized coal fired power plant, and their possible environmental effect. Inter J Coal Geol 2006; 65: 17-25.

[16] Meij R. The distribution of trace elements during the combustion of coal. In: Swaine DJ, Goodarzi F, Eds. Environmental aspects of trace elements in coal. Kluwer Academic Publishers, Dordrecht the Netherlands 1995; 7: pp. 111-45.

[17] Hower JC, Robertson JD, Graham UM, Thomas GA, Wong AS Schram WH. Characterization of Kentucky coal-combustion byproducts: compositional variations based on sulfur content of feed coal. Int J Coal Qual 1993; 12: 150-5.

[18] Goodarzi F, Huggins FE. Speciation of nickel in Canadian subbituminous and bituminous feed coals and their ash byproducts. JEM 2004; 6: 787-91

[19] Goodarzi F, Huggins FE. Speciation of arsenic in Canadian subbituminous and bituminous feed coals and their ash byproducts. Energy Fuels 2005a;19: 905-15.

[20] Goodarzi F, Huggins FE. Speciation of chromium in Canadian subbituminous and bituminous feed coals and their ash byproducts. Energy Fuels 2005b; 19: 2500-8. 
[21] Chung FH. Quantitative interpretation of X-ray diffraction patterns of mixtures. I. Matrix-flushing method for quantitative multicomponent analysis. J Appl Crystal 1974; 7: 519-25.

[22] Chung FH. Quantitative interpretation of X-ray diffraction patterns of mixtures. III. Simultaneous determination of a set of reference intensities. J Appl Crystal 1975; 8: 17-9.

[23] Finkelman RB, Palmer CA, Krasnow MR, Aruscavage PJ, Sellers GA, Dulong FT. Combustion leaching behavior of elements in the Argonne premium coal samples. Energy Fuels 1990; 4: 755-66.

[24] Goodarzi F. Characteristics and composition of ESP fly ash from Canadian coal-fired power plants. Fuel 2006a; 85: 1418-27.

[25] Putnis A, McConnel, JDC. Principal of mineral behavior, geosciences Text,V1, Elsevier, New York, 1980; p. 257.

[26] Goodarzi F. The rates of emissions of fine particles from some Canadian coal fired power plants. Fuel 2006b; 85: 425-33.

[27] Canadian environmental protection act (CEPA) Environment Canada. Catalogue No. EN21-137/1995 E: 1995

[28] Gutberlet H. Influence of furnace type on poisoning of DENOX catalysts by arsenic, VGB Krafwerkstechnik, 1988, 68: 264-71.

[29] Fergusson JE. The heavy elements: chemistry, environmental impact and health effects Pergamon Press, Oxford, England, 1990; p. 614.

[30] Ashby JR, Craig PJ. In: Harrison RM, Ed. Pollution, causes, effects, and control. The Royal Society of Chemistry. Cambridge: England 1993; pp. 309-42.

[31] Harte J, Holden C, Schneider R, Shirley C. Toxics A to Z (A guide to everyday pollution hazards). Berkeley, Los Angeles, University of California Press, 1991; 276-8.

[32] Swaine DJ. Trace Elements in Coal. Butterworths, London, England, 1990; p. 278

[33] Finkelman RB, Orem W, Castranova V, et al. Health Impact of coal and coal use: possible solutions. Inter J Coal Geol 2002; 50: 425-33.

[34] Goodarzi F, Swaine DJ. Chalcophile elements in Canadian coals. Inter J Coal Geol 1993; 15: 281-92.

[35] Huggins FE, Huffman GP, Kolker A, Mroczkowski SJ, Palmer CA, Finkelman, RB. Combined application of XAFS spectroscopy and sequential leaching for determination of arsenic specification in coal. Energy Fuels 2002; 16: 1167.

[36] Huffman GP, Huggins FE, Shah N, Zhao. Spectiation of arsenic and Chromium in coal and combustion ash by XAFS spectroscopy. J Fuel Proc Technol 1994; 39: 47-67.

[37] Beliles R P. Metals. In Toxicology - the basic science of poisons. Casarett L J, Doull J, Eds, New York: Macmillan, 1975; 585-97.

[38] Anderson RA. Nutritional role of chromium Sc. Total Environ 1981; 17: 13-29.
[39] Piperno E. Trace element emission: Aspects of environmental toxicology. In: Babu SP, Ed. Trace elements in fuel. Advances in chemistry series, No. 141. Am Chem Soc 1975; 192-209.

[40] Goodarzi F, Reyes J, Schulz J, Holman D, Rose D. Variation in mercury emission over thirty-nine weeks - Parameters influencing the variation. Inter J Coal Geol 2006; 65: 26-34.

[41] Goodarzi F. Petrology of subbituminous feed coal as guide to capture of mercury by ESP-Influence of depositional environment. Int J Coal Geol 2005; 61: 1-12.

[42] Goodarzi F. Speciation and mass-balance of mercury from coal fired power plants burning western Canadian subbituminous coal, Alberta, Canada. JEM 2004; 6: 787-91.

[43] Hower JC, Maroto-Valer MM, Taulbee DN, Sakulpitakphon T. Mercury capture by distinct ESP fly ash carbon forms. Energ Fuel 2000; $14: 224-6$.

[44] Moore JW, Moore EA. Environmental chemistry. Academic Press, New York, San Francisco, London, 1976.

[45] United State Environmental Protection Agency (US EPA), Mercury Study Report to Congress. EPA-452/R-97-007. 1997c; p. 349.

[46] World Health Organization Geneva (WHO). Trace elements in human nutrition and health, 1996.

[47] United State Environmental Protection Agency (US EPA), Mercury Study Report to Congress. EPA-452/R-97-003. 1997a; 1: p. 95.

[48] United State Environmental Protection Agency (US EPA), Mercury Study Report to Congress. EPA-452/R-97-005. 1997b; 3: p. 376.

[49] Lindberg SE, Stratton WJ. Atmospheric mercury speciation: concentrations and behavior of reactive gaseous mercury in ambient air. Environ Sci Technol 1998; 32: 49

[50] Rasmussen PE. Trace metals in environment: a geological perspective. Geol Surv Can Bull Environ Sci Technol, 1996; 429: p. 26.

[51] Goodarzi F, Sanei H, Duncan WF. Monitoring the distribution and deposition of trace elements associated with lead and zinc smelter in the Trail area. JEM 2001; 3: 515-25.

[52] Goodarzi F, Hower J. Classification of carbon in Canadian ESP fly ashes. Fuel 2007; 48: 1949-57.

[53] IARC working group on the evaluation of carcinogenic risks of chemical to humans, Some metals and metallic compounds. IARC monographs on the evaluation of the carcinogenic risk of chemicals to humans, Lyon: International Agency for Research on Cancer. 1980; 23. [MO-002705] http: //www.iarc.fr

[54] Linton WL. The control of industrial pollution. In: Harrison RM, Ed. Pollution. cause, effects and control. R Soc Chem Cambridge, U.K., 1993; 297-308.

[55] Finkelman RB. Modes of occurrence of environmentally-sensitive trace elements in coal: Environmental Aspects of Trace elements s in Coal, Swaine DJ, Goodarzi F, Eds, Kluwer Academic Publishers, Dordrecht, the Netherlands. 1995; 2: 24-50. 